BABELAO 2 (2013), p. 141-157

(C) ABELAO (Belgium)

\title{
Some Aspects of the
} Religious Organization of St. Thomas Christians during the Pre-colonial Period

By

Thomas Durant

Namur, Belgique

he religious organization of the st. Thomas Christians in the pre-colonial period is often discussed as a secondary matter. The reasons are numerous, but the main one seems to be the lack of reliable historical sources needed to seriously tackle the question. Nevertheless, we will try, using historical sources and concepts of social anthropology, to see things differently and to defend a hypothesis from Louvain-laNeuve often neglected by academic literature. Thus, we will try to present an overview of the social and religious organization of Indian Christians.

It should, however, be specified that our ambition is limited. Firstly, for historical reasons, we shall only consider the southern Indian subcontinent and particularly, Kerala. Next, it should be noted that the arrival of the Portuguese in the fifteenth century brought many political and religious changes. The Christian 
religious organization was significantly modified, which is why this article will focus on the period from early Christianity to the arrival of European settlers.

In the first part of this article, we will try to trace the origin of the first Christians in India. In the second part, we shall present some elements specific to their social and religious organization.

\section{The arrival of Christians in India}

The arrival of the first Christians in India is a subject which is extensively covered by scientific literature. It has seen two major assumptions. The first being that the apostle Thomas, with or without Bartholomew, was the first to preach Christianity in India. The second postulates that Christianity came three centuries later with the migration of merchants and missionaries from the Church of Persia.

\section{An apostolic origin?}

This first hypothesis is that the apostle Thomas, a disciple of Jesus, founded the first Christian community in India. It is defended by many researchers ${ }^{1}$ and the oral tradition of Indian Christians themselves. Several sources come to reinforce this hypothesis. We'll create a distinction between the ancient sources and later sources.

Among the ancient written sources, first let us note the Gospel of John, which mentions the existence of an apostle named Thomas $^{2}$. His life and his martyrdom would be recounted in The Acts of Judas Thomas, an apocryphal literature from the third century. Even if we can distinguish several different traditions, the numerous miraculous passages cast doubt on the historical value of this document ${ }^{4}$. However, research has been conducted on the plausible elements of the story. This leads us to believe that Thomas preached in northern India (in the kingdom of the Parthian king Gundaphar) before travelling to the South, on the Coromandel Coast, where he supposedly suffered the martyrdom ${ }^{5}$. Other written sources (St. Gregory Nazianzus, St. Ephrem of Edessa, St. Ambrose, ...) also bind the apostle Thomas

\footnotetext{
${ }^{1}$ For more information : M. MUNDADAN, History of christianity in India, Bangalore, 1984, p. 21.

${ }^{2} \mathrm{Jn} 11,16$

${ }^{3}$ Y. TISSOT, Les actes de Thomas, exemple de recueil composite, in F. BOVON et al. (eds.), Les actes apocryphes des apotres, Genève, 1981, p. 223-232. For more information about the text: M. GEERARD, Clavis Apocryphorum Novi Testamenti, Turnhout, 1992, $\mathrm{n}^{\circ} 245 . \mathrm{i}$ (recensio syriaca) and 245.ii (versio graeca).

4 A. PORATHOOR, art. "The acts of Thomas", in The st. Thomas christian encyclopaedia of India, vol. 2, Trichur, 1973-2010, p. 24-27.

${ }^{5}$ Mundadan, History, p. 26.
} 
with India ${ }^{6}$. Some researchers offer the hypothesis that the author's weak geographical knowledge have misled them ${ }^{7}$. We do not follow this argument, travel over land has been known since the time of Alexander the Great at least ${ }^{8}$. In addition to this, knowledge of the monsoons necessary for the sea travel had been growing in the West since the first half of the first century'.

As for ancient Indian sources, the literature is not nearly as rich. Firstly, the climate of the time was not suitable for the drafting of written documents ${ }^{10}$. Secondly, many texts were destroyed at the synod of Diamper. We do possess some archaeological remains; however it seems difficult to use the method of carbon-14 dating on some of them ${ }^{11}$. Nevertheless, the most optimistic estimate that some stone crosses may date back to the second century ${ }^{12}$.

Indian oral tradition is particularly rich, but it seems difficult to date it with any confidence before the fifteenth century ${ }^{13}$. However, nothing prevents us from believing that its origin goes back further. This tradition is composed of many hymns and songs in praise of St. Thomas, including for example: Thomas parvam, the song Veeradian, the song of Rabban Thomas, the Margamkali dance and many more amongst many others ${ }^{14}$. The correspondences between the oral tradition and the acts of Judas Thomas are numerous ${ }^{15}$. Some archaeological remains reinforce some of these traditions, but we will return to that later.

Among the later Western sources, we find, for example, Marco Polo who mentions what could be the tomb of the apostle Thomas $^{16}$. The arrival of the Portuguese also heralded a rich production of written documents. However, prudence is in order for many elements may have been modified or omitted either for ideological reasons or through simple ignorance. This rich production can be explained by the enthusiasm of the Portuguese towards the worship of saints and relics ${ }^{17}$. Three traditions may be

${ }^{6}$ For the complete references of these authors and many more: A.E. MeDlycotT, India and the Apostle St Thomas, London, 1905.

${ }^{7}$ H. COMES, art. "Did St. Thomas really come to India", in The st. Thomas christian encyclopaedia of India, vol. 2, Trichur, 1973-2010, p. 23-24.

${ }^{8} \mathrm{~V}$. VithayathiL, art. "Mission and life of St. Thomas in India", in The st. Thomas christian encyclopaedia of India, vol. 2, Trichur, 1973-2010, p. 2-5.

9 P. Malekandathil, "St. Thomas Christians and the Indian Ocean: 52AD to 1500AD", Christian Orient 5 (2001), p. 175-202.

${ }^{10} \mathrm{~J}$. MADEY, "La chrétienté de Saint-Thomas en Inde : Eglise catholiques et orthodoxes", Irénikon 65 (1992), p. 24-41.

11 E.R. HAmbYE, art. "Excavations at S. Tome-Mylapore", in The st. Thomas christian encyclopaedia of India, vol. 2, Trichur, 1973-2010, p. 5-7.

12 R.E. FrYKENBERG, Christianity in India : from beginnings to the present, Oxford, 2008, p. 99.

${ }^{13}$ FRYKENBERG, Christianity in India, p. 99-100.

14 P.J. PODIPARA, art. "The indian apostolate of St. Thomas", in The st. Thomas christian encyclopaedia of India, vol. 2, Trichur, 1973-2010, p. 7-12.

15 PODIPARA, "The indian apostolate of St. Thomas", p. 9.

16 M. POLO, Le devisement du monde : le Livre des merveilles, Paris, 1996, p. 400.

${ }^{17}$ Mundadan, History, p. 54. 
distinguished from these writings: that of Malabar, that of the Eastern Church, and finally that of Mylapore ${ }^{18}$. Firstly, they all agree on the fact that the apostle Thomas experienced martyrdom in India and that his tomb is located on the coast of Coromandel. Archaeological remains of this have also been found and the size of brick indicates that it dates back to before the second century ${ }^{19}$, while the pieces of spear found inside strengthen the tradition of Malabar ${ }^{20}$. Without duplicating the debate on this tomb, it should be noted that there are still arguments that cast doubt on its authenticity ${ }^{21}$. Secondly, the three traditions assert that a Christian community existed on the Coromandel coast that, following a natural disaster or disagreement (religious or not), migrated to the coast of Malabar ${ }^{22}$. This community was on the decline until the arrival of traders and immigrants from the Church of Persia.

As we have seen, some evidence suggests that the apostle Thomas (or other Christians) could have reached India from the first century A.D. However, not all the elements in our possession justify such an assumption. We will now examine whether these are sufficient to reject the idea of an Indian Christianity before the fourth century.

\section{A divergent view}

To present the elements that cast doubt on the apostolic presence, we will take one of the articles by Comes in st. Thomas Christian Encyclopedia of India ${ }^{23}$. Whenever possible, we will try to nuance the elements advanced.

The first argument concerns the prestigious oral tradition. As we have already mentioned, it is difficult to verify its existence in versions that have survived before the fifteenth century. Moreover, as we shall later see, a famous founder was necessary to strengthen the identity of the first Christian groups. We allow for true idea that history has therefore been amended accordingly.

A second argument advances that it is unlikely that a disciple of Christ, except Peter, could have left Jerusalem before 50 . According to oral tradition, Thomas arrived in 52 on the subcontinent. Even if covering such a distance by land was possible in two years, Comes highlights that the many Jewish communities on the road to India would have occupied the apostle for at least a lifetime ${ }^{24}$. However, nothing prevents us from thinking that the apostle joined India by sea ${ }^{25}$, or even if it is

\footnotetext{
18 Mundadan, History, p. 40-41.

19 G. SChurhammer, art. "The tomb of Mailapur", in The st. Thomas christian encyclopaedia of India, vol. 2, Trichur, 1973-2010, p. 5.

20 PODIPARA, "The indian apostolate of St. Thomas", p. 9.

${ }^{21}$ MUNDADAN, History, p. 59.

${ }^{22}$ MUNDADAN, History, p. 75.

${ }^{23}$ Comes, "Did St. Thomas", p. 23.

24 Comes, "Did St. Thomas", p. 23.

${ }^{25}$ Malekandathil, "St. Thomas Christians", p. 175-177.
} 
less likely, that he made two trips to India ${ }^{26}$, precisely because some Jewish communities were already present at Muziris (now known as Cranganore) at that time ${ }^{27}$.

Another element pointed out by Comes refers to the similarities between the liturgy of the Christians of the East and that of the Indian Christians ${ }^{28}$. The author hypothesizes that the liturgy of the East could not have imposed itself so quickly. We will go into more depth about the scope of these similarities, let us note for now that the synod of Diamper, for example, substantially changed a centuries old liturgy in very little time.

Comes also cites a list of Christian authors who do not mention the existence of Christians in India. However, we will remain cautious vis-à-vis these authors. While Tertullian does not mention India, he does say, though, that Christians were present in Parthia ${ }^{29}$. Similarly, Origen says that Christians were absent in Ariake $^{30}$, supposedly a region near Bombay, but we do not know if this assertion is limited to this region or to the whole of India.

Finally, on the side of history and its interpretation, it was only from the third century onwards that a large Christian community was organized to the east of the Tigris, a fortiori, the progression of Christianity would have taken place even later in India ${ }^{31}$. However, according to Indian and Portuguese tradition, the Christian community, before the fourth century, was on the decline. Thus, our hypothesis does not completely contradict this interpretation of history.

\section{The arrival of the Christians of the East}

As we have seen, many elements suggest that Christianity developed in India from the first century. However for some researchers all is dubious until the arrival of immigrants from the Church of the East in 345. After this date, the Christian presence in India is firmly attested by tablets of copper and tablets of stone $^{32}$.

According to tradition, no less than 400 Christian immigrants, divided into 72 "royal" families, were led by the Judeo-Christian

26 A.K. THOMAs, The Christians of Kerala : a brief profile of all major churches, Kottayam, 1993, p. 17.

27 T. PUTHIAKUNNEL, art. "Jewish colonies of India paved the way for St. Thomas", in The st. Thomas christian encyclopaedia of India, vol. 2, Trichur, 19732010, p. 26-27. F. HOUTART - G. LEMERCINIER, Genesis and institutionalization of the indian catholicism, Louvain-la-Neuve, 1981, p. 6.

${ }^{28}$ COMES, "Did St. Thomas", p. 23.

29 Adversus Iudaeos, VII, 4 (in E. Kroymann, Tertullianus. Opera [Corpus Christianorum. Series Latina 2], Turnhout, 1954, p. 1354).

${ }^{30}$ Comes, "Did St. Thomas", p. 23.

31 COMES, "Did St. Thomas", p. 23.

32 FrYKenBerG, Christianity in India, p. 107. For more information about these tablets: see note 45 . 
Thomas Kinayi ${ }^{33}$ to Muziris in $345^{34}$. Note however that all Portuguese sources date the arrival of Thomas Kinayi well after the fourth century ${ }^{35}$. This may be due to a confusion of names or to the fact that some of the Indian oral tradition was constituted well after the arrival of Thomas Kinayi ${ }^{36}$. The Christians then enjoyed unprecedented prosperity, with land and various other privileges being granted to them. These are documented in the tablets listed above. The date of this migration is also consistent with the persecution suffered by the Christians of the East after the conversation of the Roman Empire, the Sassanid enemy, to Christianity $^{37}$. In addition, this migration could also have been a way of communicating the conclusions of the Council of Nicaea, regarding in particular the hierarchy of the Church, to the Churches in Persia and Great India ${ }^{38}$.

Five centuries later the city of Quilon, having become one of the largest ports in the region, hosted a major migration led by the brother-bishops Mar Sapor and Mar Prot ${ }^{39}$. Like Cranganore, tablets provide testament to the lands and privileges granted to the Christians ${ }^{40}$.

If we have tablets of copper regarding these two waves of migration, nothing prevents us from thinking that smaller waves of migration took place on a regular basis. Let us note that these migrations were probably made with the blessing of the Church of Persia. Many sources, all dating after the fourth and fifth centuries, suggest that this Church exercised a certain influence on Indian Christians ${ }^{41}$.

\section{Conclusion}

In this first section, we tried to trace the arrival of the first Christians on the Indian subcontinent. It is by design that we focus on the apostolic hypothesis. Indeed, many elements suggest that it is plausible and this choice is not without consequences for the rest of our development. Borrowing a famous phrase from Indian Christians themselves to summarize our position: "Show me the evidence for Peter going to Rome, and I shall show you the evidence for Thomas coming to India" ${ }^{2}$.

\footnotetext{
33 Sometime called "Thomas of Cana", for a complete discussion about this name: J. KOLLAPARAMBIL, The babylonian origin of the southist among the St Thomas christians, Roma, 1992, p. 1-21.

${ }^{34}$ FrYKENBERG, Christianity in India, p. 108-109.

${ }_{35}$ Mundadan, History, p. 91-93.

${ }^{36}$ KOLLAPARAMBIL, The babylonian origin, p. 23.

${ }^{37}$ Mundadan, History, p. 84.

${ }^{38}$ KOLLAPARAMBIL, The babylonian origin, p. 65.

${ }^{39}$ MUNDADAN, History, p. 111.

${ }^{40}$ Mundadan, History, p. 111.

${ }^{41}$ S.H. MOFFET, A bistory of Christianity in Asia, New-York, 2003-2005, p. 266.

${ }^{42}$ FRYKENBERG, Christianity in India, p. 102.
} 


\section{The organization of Indian Christians}

In this second section we will begin with the integration of Christians of St. Thomas into Indian society. Then we will look at their specifically religious organization. However, before beginning, we should note that the Christians were not necessarily a unified group in Kerala during the pre-colonial period. Among the distinctions, we can make out different groups. On one hand those who claimed to be descendants of the first to be converted by the apostle, and which were known as Vatakkumbhagar or Northerners, and on the other hand, those who claimed to be the descendants of Thomas Kinayi group and were called Tekkumbhagar or Southerners ${ }^{43}$. These names transcribe the geographical reality of the organization of these groups. Thus, the first occupied the north of the urban area, while the latter occupied the south ${ }^{44}$. We cannot underestimate the symbolic importance of this difference which reflects a frank opposition. An analysis of myths suggests that such conflicts are related to differences in worship. According to this, the northerners, closer to the Brahmanic culture, were more likely to alter their rituals and their lifestyle than the southerners, who were closer to the Eastern Church ${ }^{45}$.

\section{The integration of Christians into Indian society}

Foremost, we have to remember that Indian society is a compartmentalized society. It is composed of different endogamous groups kept separate by highly symbolic social practices. Thus, each individual must know who he can approach, who he can help, who he can eat with, how he should dress, how to talk, etc. ${ }^{46}$ All of these practices are determined by birth (jat) within an extended family, which itself is part of a lineage. Each lineage tends to refer back to a common ancestor. This subdivision was maintained at the arrival of the Christians of the East. However, according to the tablets of stone and copper discovered, the Southern Christian group was relatively quickly integrated into the Keralan society ${ }^{47}$. Indeed, the rulers allowed them numerous symbolic and financial privileges. These were far from negligible and helped them occupy a particularly high social position. This rapid integration of this group of merchants by the rulers is related to their major economic role. Indian leaders depended largely on income related to the taxation of trade. But they had neither the experience nor the knowledge of astronomy

\footnotetext{
${ }^{43}$ KOLLAPARAMBIL, The babylonian origin, p. XXIII - Introduction.

44 At least in the cities of Quilon and Cranganore

${ }^{45}$ HOUTART - LEMERCINIER, Genesis, p. 36.

${ }^{46}$ FrYKEnBERG, Christianity in India, p. 35.

47 We found two tablets at Cranganore (372 and 774) and two tablets at Quilon (849). Quilon is a major port in the ninth century. For the details of these tablets: HOUTART - LEMERCINIER, Genesis, p. 9-14.
} 
needed $^{48}$ to effectively manage trade with large external powers ${ }^{49}$. If this role was already important in the fourth century, it would grow to become a crucial element in the ninth century. Indeed, their location on the Indian coast made them a first choice stopover for travelers undertaking long journeys such as Persia to China. Again, the Christians' experience in foreign trade plays an important part, but the willingness of leaders to weaken the rival religions such as Buddhism and Jainism is also an un-negligible factor $^{50}$. On their side, Christians had been seeking greater support from the rulers to compete with the arrival of Muslim traders $^{51}$.

\section{Social life}

The details of this integration had many implications for the organization of the groups of Indian Christians. They received the status of manigranam. This title, described by Houtart ${ }^{52}$, provided significant business benefits, such as the right to buy and sell all types of products. If the manigranam were sometimes perceived as merchant guilds ${ }^{53}$, they were also real social, political and religious entities $^{54}$. They were composed of several extended families, themselves composed of several units whose names vary depending on locations (kara, tawards or muris). These units consisted of a father, a mother, the father's younger brothers and all of their children, except married girls, because marriage was virilocal. They lived under one roof and had their property in common. These groups were exogamous, however endogamy was confined to the boundaries of a given manigranam, Christians from different manigramam could therefore not marry each other. Let us note that it is religion and the reference to a common ancestor, usually famous (the apostle Thomas, Thomas Kinayi, Mar Sapor and Mar Prot...), which legitimized the association of extended families. So much so that being a Christian primarily meant belonging to a well defined social group and designating membership to a religion was purely secondary.

According to the tablets, in return for various privileges granted to the manigranam, they did suffer the burden of paying taxes. According to Houtart ${ }^{55}$, it is at this level, through two separate assemblies (yogams), that were organized to involve all of the extended families: relations with political authorities, a part of justice, religious organization,... The first assembly, pothu-yogam,

48 P. Malekandathil, Maritime India: Trade, Religion and Polity in the Indian Ocean, New Delhi, 2010, p. 43.

${ }^{49}$ HOUTART - LeMERCINIER, Genesis, p. 18-19.

${ }^{50}$ MALEKANDATHIL, Maritime India, p. XVII - Introduction.

51 K.S. Kurian, Cultural Identity Crisis of Thomas Christians, The Harp 21 (2006), p. 323-336.

${ }^{52}$ HoutArT - LeMERCINIER, Genesis, p. 21-26.

53 Malekandathil, "St. Thomas Christians", p. 193-194.

${ }^{54}$ HOUTART - LEMERCINIER, Genesis, p. 21.

${ }^{55}$ HoutArt - LEMERCINIER, Genesis, p. 23. 
was composed of the heads of family, the priests and the religious property managers. The powers of this assembly were both temporal, particularly through justice, and spiritual. The second assembly, sadharana yogam, had a more pragmatic role and took charge of, among many other things, the organization of religious festivals. Finally, each manigranam was headed by a jathikeku kaethavian, later called "Archdeacon" by the Portuguese ${ }^{56}$. Let us note, however, that this status shows that the stake of a manigranam goes far beyond economics. As we see, a manigranam constitutes a kind of artificial clan or even a varna ${ }^{57}$. Hence, we understand that groups of new arrivals had to integrate into Indian society by and for themselves, and thus form a distinct manigranam. A particularly eloquent example of this is illustrated with the brother-bishops who received this title only 26 years after their arrival ${ }^{58}$.

We do not yet know if this social structure was applied in the fourth century; the word manigranam didn't appear on the oldest tablet $^{59}$. It is likely that a similar structure was quickly implemented to achieve this form through an acculturation of the Christians to the culture of the elite. This acculturation was widely promoted by the ruling powers through the symbolic and cultural elements granted to Christians since 345. Moreover, it would have been difficult for the Indian social system to enduring a variation in the structure of its different elements ${ }^{60}$. Let us note already that the social structure would not be the only element acculturated, indeed, numerous social and cultural practices were modified in the fashion of the culture of the elite. These practices are listed and partially described in the acts of the synod of Diamper ${ }^{61}$.

We do not know in fact if this type of structure was also applied to northerners, but it seems that we can assume it. Indeed, this structure was, as we have said, very close to the Indian structure. Now, in keeping the assumption that we defend, the northerners were the descendants of the first families of Brahman converted by the apostle Thomas. Hence, their structure should have been similar. Moreover, we know that both groups enjoyed an elevated social status ${ }^{62}$.

\section{Professional life}

As we have seen, the southerners quickly integrated themselves and played a major economic role. The latter was further strengthened from the ninth century onwards. Several

${ }^{56}$ Literally: the lord of the nation.

${ }^{57}$ MALEKANDATHIL, Maritime India, p. XVII - Introduction.

${ }^{58}$ MaLEKANDATHIL, Maritime India, p. 40.

${ }^{59}$ HOUTART - LEMERCINIER, Genesis, p. 9-10.

${ }^{60}$ Houtart - Lemercinier, Genesis, p. 25.

${ }^{61}$ For an excellent synthesis of these : P. PALLATH, "St. Thomas Christian Church before Sixteenth Century : A model for Inculturation", Ephrem's Theological Journal 6 (2002), p. 3-32.

${ }^{62}$ Houtart - Lemercinier, Genesis, p. 28. 
factors were crucial. Among them we have to mention, once again, their experience, their suitable geographic location, their knowledge of astronomy and the willingness of their rulers to weaken rival religions. However, we can not underestimate the importance of financial income derived from the taxation of commerce. These revenues were crucial to the political powers that had to cope with conflicts generated by neighboring kingdoms ${ }^{63}$. All of this greatly facilitates the perception of manigranam as a merchant guild. However, as we have seen, these entities also had an important political and religious role. These groups of extended families were closer to the concept of jatt ${ }^{64}$. The latter refers to endogamous groups, usually named according to the profession to which they are associated and whose membership is defined by birth (jat) ${ }^{65}$. The social status of the group is not determined in advance and then depends on its size and on its economic role in the region concerned ${ }^{66}$. For Southerners, it's obvious that the profession would have been traders ${ }^{67}$.

According to Malekandathil ${ }^{68}$, the northerners, meanwhile, specialize in the cultivation of pepper, although it could have been already their sector of activity before their conversion by the apostle. Many churches were built in the fertile areas of the interior of Kerala. Indeed, between the fourth and seventh centuries, a little less than 20 major churches were built near the irrigable areas. Some links, based on their share beliefs, would then have been created between southerners and northerners with the formers selling the latter's production. Many changes, climatic, economic and political took place from the ninth century. These changes would push the northerners to quickly adapt and to deploy their activity more deeply to the hinterland. Once again, it is the building of churches that allows us to follow the northerners among the fertile areas of the time. As we have seen, a new wave of migration, led by the brother-bishops, arrived in Quilon in the ninth century. At that time, Quilon was economically more dynamic than Cranganore. Thus the commercial alliance between northerners and southerners was probably renewed. However, this period of financial prosperity would soon be challenged by the arrival of Muslims on the Indian coast. From the thirteenth century onwards, the Southerners weathered a crisis directly related to competition, while the northerners faced natural disasters. Consequently, the latter adapted their activities and continued to extend in the direction of the most fertile areas. Let us note that even today the name of st. Thomas Christians is associated with the production of pepper

\footnotetext{
${ }^{63}$ MaleKandathil, Maritime India, p. 42.

${ }^{64}$ HoutART - LEMERCINIER, Genesis, p. 21.

65 R. Deliège, Les castes en Inde aujourd'hui, Paris, 2004, p. 29-30. M. STUTLEy - J. STUTLEY, A dictionary of Hinduism, London, 1977, p. 128.

${ }^{66}$ DeLIÈGE, Les castes en Inde aujourd'bui, p. 30.

${ }^{67}$ MaleKandathil, Maritime India, p. 44.

${ }^{68}$ MaleKandathil, "St. Thomas Christians", p. 175-202.
} 
and spice ${ }^{69}$. Besides this activity, the northerners also seemed, like the nayars, to be excellent soldiers ${ }^{70}$.

It should be noted that this type of business alliance, based on shared beliefs, was not at all improbable. Indeed, this same pattern occurred when the Portuguese arrived in Kerala ; Indian Christians tried to compete with Muslim merchants through this kind of alliance ${ }^{71}$.

\section{Religious structure}

After briefly introducing the integration and organization of Indian groups in the Keralan society, we will now discuss their specifically religious organization. To do this, we will try to draw conclusions based on the evidence we have put forward so far. That done, we will discuss the links between Indian Christians and the Church of Persia. Finally, we will quickly discuss the role of a historical figure known as the "Archdeacon of all India."

\section{No global religious institution}

Throughout our progress, we have attempted to highlight the existence of different closed groups. As we have seen, they were diverse. Each group integrated itself by itself and some even had different ethnic backgrounds. If shared beliefs probably played a role to the promotion of contacts between these groups, we do not think, however, that this was done through a global religious institution. We will quickly introduce some elements that suggest this to be the case.

Firstly, Indian society, as we have said, encouraged the partitioning of different groups. Portuguese sources are unanimous in saying that northerners and southerners were in conflict, to the point of building different churches for one and the other ${ }^{72}$. This conflict could be both social and racial ${ }^{73}$, northerners wishing to integrate fully into the Hindu hierarchy, especially following the Aryanization of the eighth century ${ }^{74}$. Southerners, meanwhile, placed more emphasis on their ethnic purity and were more reluctant to make changes vis-à-vis their rite of origin, namely that of the Church of Persia ${ }^{75}$.

Secondly, no western sources that we know of mention the existence of an ecclesiastical structure. Travelers, in any case, should have at least known the Latin model $^{76}$. This element would

\footnotetext{
${ }^{69}$ MaleKandathil, "St. Thomas Christians", p. 181.

${ }^{70}$ Mundadan, History, p. 155.

${ }^{71}$ HOUTART - LEMERCINIER, Genesis, p. 49.

72 HoutArT - LEMERCINIER, Genesis, p. 29.

73 P. J. Podipara, "The syrian church of Malabar", in G. MENACHery (ed.), The Nazranies, Pallinada, 1998, p. 363-375.

${ }^{74}$ HOUTART - LEMERCINIER, Genesis, p. 33.

${ }^{75}$ Houtart - Lemercinier, Genesis, p. 36.

${ }^{76}$ Houtart - LeMErcinier, Genesis, p. 27.
} 
have been even more evident if, like the Church of Persia from which some Christians came, the church structure was centralized and rigid ${ }^{77}$.

Finally, differences in ritual can be observed between different groups of Christians. Indeed, the southern group, related to the arrival of Thomas Kinayi were more inclined to adopt practices closer to Jewish practices ${ }^{78}$. This can be explained by the fact that Thomas Kinayi and his group were predominantly JudeoChristian $^{79}$. However, the links between Indian Christians and the Church of Persia, as well as the existence of a historical figure known as the "Archdeacon of all India" are two elements that might challenge our hypothesis. As we shall see, these have to be put into the perspective of the period under consideration.

\section{The relationship between the Church of Persia and the Indian Christians}

Links between Indian Christians and the Church in Persia are widely documented. First, we have various historical documents, letters, testimony... ${ }^{80}$ But in addition, as we have seen, several Christian groups came from the Church of Persia. However, researchers do not all agree on the intensity of these links. Some reduce them to a single "canonical" link ${ }^{81}$, while others argue that the survival of the Church depended on links with an international church, being wiser and who held authority ${ }^{82}$.

With these historical elements, all dating after the fifth century, we learn a little more about these links. Firstly, the bishops of the Church of Persia came to India sporadically ${ }^{83}$. The links were probably not continuous. In addition, their role was probably limited to spiritual support for the communities of India. Indeed, their meager knowledge of local languages would have greatly reduced their influence. Furthermore, communities, as we have seen, had rigid structures. The inclusion of a new member with wide powers would have been more than problematic. Moreover, no eastern Episcopal see seems to have been really established in India for the period under consideration ${ }^{84}$.

In the letters of the patriarchs Mar Isoshab III (647/8 - 650/1) and Mar Timothy I (789-823 or 780), we learn that there was a dependence between Indian Christians and the Church of

${ }_{77}$ R. LE COZ, Histoire de l'Eglise d'Orient : Chrétiens d'Irak, d'Iran et de Turquie, Paris, 1995 , p. 73.

78 G. MenACHERY, "Aspects of the Idea of "Clean and Unclean" among the Brahmins, the Jews, and the St. Thomas Christians of Kerala", The Harp 22 (2007), p. 311-330.

${ }^{79}$ KOLLAPARAMBIL, The babylonian origin, p. XXIII - Introduction.

80 T. PallipurathukUnNel, "The Life and Ministry of the Indian Church Before the Synod of Diamper", Christian Orient $\mathrm{n}^{\circ}$ ? (1993), p. 170-180.

${ }^{81}$ HOUTART - LEMERCINIER, Genesis, p. 27-28.

82 Moffet, $A$ bistory, p. 269.

83 PODIPARA, The syrian church of Malabar, p. 367.

${ }^{84}$ PallipurathukunNel, "The Life", p. 171-173. 
Persia ${ }^{85}$. However, this dependency was probably legal and symbolic only. Moreover, after the ninth century, the Indian Church had to answer only to the Patriarch himself. Indeed, a number of the Church of Persia's rules were not implemented in India. For example, if the remarriage of priests was allowed for Persian Christians ${ }^{86}$, it's difficult to imagine how it could have taken place in India. The testimony of Joseph the Indian even tells us that the Christian priests practiced conjugal chastity. However, it is not understood as a chastity in the strictest sense but more like the prohibition of remarriage after the death of one's wife ${ }^{87}$.

If remarriage seems so unlikely, it is precisely because the Christians were largely acculturated to Indian culture. Podipara even said, about the Indian Christians, that they were "Hindu in Culture, Christian in Religion and Oriental in Worship". The process of acculturation was impressive and the examples of rites and customs borrowed from Indian culture are numerous. Before developing any examples, let us note that one author of note saw in these practices a true model of inculturation ${ }^{88}$, while another reduced them to "superstitious practice" ${ }^{189}$. We disagree with both of these stances.

The first, Pallath, worked impressively to inventory the many fields of life changed by the cultures and religions of India. However, we do not completely agree with the vocabulary used. If it seems obvious that the Christians were influenced by Indians, the contrary movement, necessary in a process of inculturation ${ }^{90}$, seems difficult to prove for the period in question. Comparative studies, between regions of India in which Christianity was absent and Kerala, could perhaps highlight such a contrary movement. However, we do not exclude the fact that the absence of a global religious institution could have considerably slowed down genuine Christian influence on Indian culture. It should be noted that this influence becomes clear after the arrival of the Portuguese, bringing a centralized church structure but the number of sources available on this period is more significant too, so the question remains open.

The work of the second, Pallipurathukunnel, is equally impressive. If we willingly follow the author when he shows us that the core of the Eastern rite was present in the religious celebrations of Indian Christians, we believe that elements from the dominant culture were just as important in the religious celebration. For example, let us consider the addition of a thread to the habit of the child at baptism. This thread consists of three

\footnotetext{
85 PallipurathukUnNel, "The Life", p. 176.

${ }^{86}$ LE COZ, Histoire de l'Eglise, p. 71.

${ }^{87}$ Pallipurathukunnel, "The Life", p. 177.

88 Pallath, St. Thomas, p. 3.

89 PallipurathukunNel, "The Life", p. 174-175.

90 B. BAYILI, Culture et inculturation : approche théorique et méthodologique, Paris, 2008, p. 122.
} 
strands and resembles the Brahmanic sacred thread worn by Indians, except that it is worn around the neck and not on the shoulder. If, in the case of India, the three strands represent the Trimurti, in the case of Christians they represent the Holy Trinity ${ }^{91}$. This use would have been borrowed from the Hindus to be symbolically reinvested by Christians. Similarly, while the Hindus wished to attract divine protection by such use, Christians wished to enlist the help of the saints ${ }^{92}$. In addition to its specifically religious function, clothing, including the thread, would have played an important role in the integration and affirmation of the social status in Indian society. This is just one example among others of the specificity of Christianity in India, however, it seems difficult to reduce these uses to the status of "superstitious practices". The Portuguese were not fooled, even if they did sometimes recognize the celebrations as Christian ${ }^{93}$, they prohibited many practices at the synod of Diamper. The symbolic importance of the latter was considerable, in any case, sufficient to slow down the assertion of the Latin rite. Before proceeding and to illustrate the freedom of the Christians in India vis-à-vis the Church of Persia, let us stop to consider educational practices, as these were also highly acculturated. Future priests were trained and received by a priest already operating and known for his qualities. In this was the candidate received the liturgical and spiritual heritage of the community. This institution named malpanate appears more like the Hindu institution of gurukula vidyabhyasam than that of the Church of Persia ${ }^{94}$. Similarly, the children were receiving their education, intellectual and religious, from a panicar, that was rarely non-Hindu ${ }^{95}$. They were also responsible for teaching the catechism and the main Christian prayers $^{96}$. We could multiply examples to show that Keralan Christians were much closer to the Indian elite than the Church of Persia. Without doubting the Christianity of the practices in India, which is rarely questioned ${ }^{97}$, we believe that the influence of the Church of Persia on the Christians of Kerala was relatively limited.

Finally, for the record, let us note that a priest from Malabar, sent to Portugal in 1501, would have even confused the Jacobite Patriarch of Antioch with the Catholicos of Seleucia ${ }^{98}$. This allow us to think that there was indeed a lack of knowledge of the hierarchical structure of the Church of Persia. To round off, let us also note that we do not know if this limited influence of the

91 J. MOOLAn, "St.Thomas Christian Baptismal Adaptations", Christian Orient 28 (2007), p. 76-82.

92 MoOlan, "St.Thomas Christian Baptismal Adaptations", p. 78.

93 Pallipurathukunnel, "The Life", p. 175.

94 Pallath, St. Thomas, p. 26.

${ }^{95}$ M. Mundadan, "Cultural Communication-Encounter of the St. Thomas Christians with the Hindus in Kerala", Journal of Dharma 24 (1999), p. 244-254.

96 Pallipurathukunnel, "The Life", p. 178.

${ }^{97}$ P. Pallath, The eucharistic liturgy of the St Thomas Christians and the synod of Diamper, Kottayam, 2008, p. 20 et passim.

98 PODIPARA, The syrian church of Malabar, p. 366. 
Church of Persia concerned all Christian groups or only a few of them.

\section{The Archdeacon of All India}

As we have seen, the influence of the Church of Persia on Indian Christians was relatively limited. On this basis, we can conclude that this church was insufficient to unify all Indian Christians. However, there are historical traces, all dating after the ninth century, that attest the existence of a historical figure known as"Archdeacon of all India".

For some authors, such as Pallath, this character unified Christianity in India, or was evidence that the Christianity was unified". He would be the "national unifying head" and a "celibate and native priest" who exercised power through yogam ${ }^{100}$. Description of the role and powers of the Archdeacon inevitably makes us think of the jathikku kaethavian, who was the head of a manigranam. Let us remember that this title has sometimes been translated as "archdeacon". If we do not question the prestige and the role of this historical figure, we do not think though that he had authority over all of the Indian Christians. At best, he represented all Southerners closer to the Church of Persia, where this title was born. More likely, the archdeacon was the head of a single manigranam and this institution was specific to a particular group. A different hypothesis is that more than one archdeacon existed at any one time ${ }^{101}$, for example, one for each manigranam in the south. Mundadan also argued that this character began to have a major influence only after the sixteenth century and during the seventeenth century ${ }^{102}$.

\section{CONCLUSION}

As we have seen, the origin of Indian Christians goes back to the beginnings of Christianity itself. These were quickly integrated into Indian society and several waves of migration strengthened the Christian presence. These groups were largely acculturated by the Indian religions and cultures, as their lifestyle undoubtedly show us. We believe that this influence is also exerted on the organization of Christians themselves, so much so that neither the Church of Persia neither a central figure could have unified all of them. If shared beliefs and economic factors have facilitated contacts between different groups, cultural pressure and ethnic differences made the unification of the Indian Christians under a single church difficult, if not impossible. The arrival of the

\footnotetext{
${ }^{99}$ Pallath, "St. Thomas", p. 11.

100 Pallath, "St. Thomas", p. 10.

101 MUNDADAN, History, p. 160.

102 Mundadan, History, p. 160-161.
} 
Portuguese would contribute to further fragmentation of the Christian groups. Therefore, the only true unified Church in India, incorporating all of the Indian Christians, was the one existing before the arrival of the first group of oriental merchants. Precisely, the only community whose existence we are not absolutely sure of.

\section{BIBLIOGRAPHY}

B. BAYILI, Culture et inculturation : approche théorique et méthodologique, Paris, 2008.

H. Comes, art. "Did St. Thomas really come to India", in The st. Thomas christian encyclopaedia of India, vol. 2, Trichur, 1973-2010, p. 23-24.

R. DeliÈGE, Les castes en Inde anjourd'hui, Paris, 2004.

R.E. FRYKENBERG, Christianity in India: from beginnings to the present, Oxford, 2008.

M. GEERARD, Clavis Apocryphorum Novi Testamenti, Turnhout, 1992.

E.R. HAmBYE, art. "Excavations at S. Tome-Mylapore", in The st. Thomas christian encyclopaedia of India, vol. 2, Trichur, 1973-2010, p. 5-7.

F. Houtart - G. Lemercinier, Genesis and institutionalization of the indian catholicism, Louvain-la-Neuve, 1981.

J. KOLLAPARAMBIL, The babylonian origin of the southist among the St Thomas christians, Roma, 1992.

K.S. KURIAN, "Cultural Identity Crisis of Thomas Christians", The Harp 21 (2006), p. 323-336.

R. LE Coz, Histoire de l'Eglise d'Orient: Chrétiens d'Irak, d'Iran et de Turquie, Paris, 1995.

J. MAdey, "La chrétienté de Saint-Thomas en Inde : Eglise catholiques et orthodoxes", Irénikon 65 (1992), p. 24-41.

P. Malekandathil, Maritime India: Trade, Religion and Polity in the Indian Ocean, New Delhi, 2010.

P. Malekandathil, St. Thomas Christians and the Indian Ocean: 52AD to 1500AD, Christian Orient 5: 2 (2001), p. 175-202.

A.E. MeDlyCOTT, India and the Apostle St Thomas : An Inquiry, with a Citrical Analysis of the Acta Thomae, London, 1905.

G. Menachery, "Aspects of the Idea of "Clean and Unclean" among the Brahmins, the Jews, and the St. Thomas Christians of Kerala", The Harp 22 (2007), p. 311-330. 
S.H. Moffet, A bistory of Christianity in Asia, New-York, 20032005.

J. Moolan, "St.Thomas Christian Baptismal Adaptations", Christian Orient 28 (2007), p. 76-82.

M. Mundadan, "Cultural Communication-Encounter of the St. Thomas Christians with the Hindus in Kerala", Journal of Dharma 24 (1999), p. 244-254.

M. Mundadan, History of christianity in India, Bangalore, 1984.

P. Pallath, The eucharistic liturgy of the St Thomas Christians and the synod of Diamper, Kottayam, 2008.

P. Pallath, "St. Thomas Christian Church before Sixteenth Century : A model for Inculturation", Ephrem's Theological Journal 6 (2002), p. 3-32.

T. Pallipurathukunnel, "The Life and Ministry of the Indian Church Before the Synod of Diamper", Christian Orient 4 (1993), p. 170-180.

P.J. PODIPARA, art. "The indian apostolate of St. Thomas", in The st. Thomas christian encyclopaedia of India, vol. 2, Trichur, 19732010, p. 7-12.

P.J. Podipara, The syrian church of Malabar, in G. Menachery (ed.), The Narranies, Pallinada, 1998, p. 363-375.

M. Polo, Le devisement du monde : le Livre des merveilles, Paris, 1996.

A. Porathoor, art. "The acts of Thomas", in The st. Thomas christian encyclopaedia of India, vol. 2, Trichur, 1973-2010, p. 2427.

T. PuthiakunNel, art. "Jewish colonies of India paved the way for St. Thomas", in The st. Thomas christian encyclopaedia of India, vol. 2, Trichur, 1973-2010, p. 26-27.

G. SCHURHAMmer, art. "The tomb of Mailapur", in The st. Thomas christian encyclopaedia of India, vol. 2, Trichur, 1973-2010, p. 5.

M. Stutley and J. Stutley, A dictionary of Hinduism, London, 1977.

A.K. THOMAs, The Christians of Kerala : a brief profile of all major churches, Kottayam, 1993.

$\mathrm{Y}$. Tissot, Les actes de Thomas, exemple de recueil composite, in $\mathrm{F}$. Bovon, M. van Esbroeck, R. Gouglet, E. Junod, J.-D. Kaestli, F. Morard, G. Poupon, J.-M. Prieur and Y. Tissot (ed.), Les actes apocryphes des apotres, Genève, 1981, p. 223-232.

V. Vithayathil, art. "Mission and life of St. Thomas in India", in The st. Thomas christian encyclopaedia of India, vol. 2, Trichur, 1973-2010, p. 2-5. 